\title{
Effect of Feeding Artocarpus heterophyllus, Terminalia bellerica and Carica papaya Plant Leaves on Rumen Microbial Enzymes and Growth Performances in Assam Hill Goat
}

\author{
Purabi Thakuria ${ }^{1}$, Rita Nath ${ }^{2}$, Dhrubajyoti Kalita ${ }^{2}$, Probodh Borah ${ }^{3}$, Champak Barman ${ }^{*}$, Krishna Sharma ${ }^{5}$, \\ Satya Sarma ${ }^{2}$ and Rajib Sharma ${ }^{5}$ \\ ${ }^{1}$ Aninal Health Centre, NERDDL, Animal Husbandry \& Veterinary Department, Govt. of Assam, Khanapara, Assam, INDIA \\ ${ }^{2}$ Department of Veterinary Biochemistry, College of Veterinary Science, AAU, Khanapara, Guwahati, Assam, INDIA \\ ${ }^{3}$ Department of Animal Biotechnology, College of Veterinary Science, AAU, Khanapara, Guwahati, Assam, INDIA \\ ${ }^{4}$ Department of Veterinary Physiology, College of Veterinary Science, AAU, Khanapara, Guwahati, Assam, INDIA \\ ${ }^{5}$ Department of Veterinary Microbiology, College of Veterinary Science, Assam Agricultural University, Khanapara, Guwahati, \\ Assam, INDIA \\ "Corresponding author: C Barman; E-mail: drchampak80@gmail.com
}

Accepted: 18 Nov., 2020

\begin{abstract}
In this study, three medicinal plants viz. Artocarpus heterophyllus (Jackfruit), Terminalia bellerica (Bhumura) and Carica papaya (Papaya) were investigated for their effect on the rumen enzyme profiles and growth performances in Assam hill goat. A total of eighteen (18) Assam Hill (local) goats of 3-4 months of age were procured and reared in the Experimental Animal Shed, Department of Veterinary Physiology, College of Veterinary Science, Assam Agricultural University, Khanapara, Guwahati, Assam, India. The animals were divided into three groups viz. control receiving substrate ration, $\mathrm{T}_{1}$ with plant leaves @ $5 \%$ level and $\mathrm{T}_{2}$ groups @ $10 \%$ level of total mixed ration (TMR). The duration of the experiment was 90 days (from March, 2016 to May, 2016). The fibre degrading microbial enzymes viz. carboxymethyl cellulase, endoxylanase, $\beta$ - glucosidase were estimated in rumen liquor of the animals during the study period and rumen liquor analysis revealed that out of the three rumen fibrolytic enzymes, Carboxymethyl cellulase showed better $(\mathrm{P}<0.05)$ enzyme activity in $\mathrm{T}_{2}$ group $(2.83 \pm 0.01 \mu \mathrm{mol}$ glucose/ $\mathrm{ml} / \mathrm{h})$. The average body weight $(\mathrm{kg}$ per animal) recorded in the present experiment showed significant trend $(\mathrm{P}<0.01)$ from 0 to 90 days of experiment where higher value $(9.62 \pm 0.43 \mathrm{~kg} /$ animal $)$ was obtained in $\mathrm{T}_{2}$ group. From this study, it can be concluded that these three medicinal plants viz., A. heterophyllus, C. papaya, T. bellerica do not have any harmful effect on normal functioning of the rumen. Thus, the plant leaves can be incorporated in the diet up to $10 \%$ of the total mixed ration.
\end{abstract}

\section{HIGHLIGHTS}

(0 The medicinal plants viz., A. heterophyllus, T. bellerica and C. papaya, are important for normal functioning of the rumen of animals.

(0 These leaves can be incorporated in the diet of animals up to $10 \%$ of the total mixed ration.

Keywords: Assam hill goat, enzyme, plant, rumen, total mixed ration

Livestock production is a vital component of the Agricultural Industry in India. About 20.5 million people in India depend upon livestock for their livelihood and much effort is being directed towards improving this sector. Goats (Capra hircus) are the dominant small ruminants that play a significant role in the rural economy of India. India possesses second largest goat population in

How to cite this article: Thakuria, P., Nath, R., Kalita, D., Borah, P., Barman, C., Sharma, K., Sarma, S. and Sharma, R. (2020). Effect of feeding Artocarpus heterophyllus, Terminalia bellerica and Carica papaya plant leaves on rumen microbial enzymes and growth performances in Assam hill goat. J. Anim. Res., 10(6): 961-966.

Source of Support: None; Conflict of Interest: None क्) 
the world which is 135.2 million. It provides an alternative source of livelihood to the farmers all the year round. In Assam, the population of goats is 61.69 lakhs $\left(19^{\text {th }}\right.$ Livestock Census, 2012) and mostly reared by the poor and landless farmers of rural areas. The main constrain to goat production is the lack of feed, particularly in the dry season that affects the productivity (Phengsavanh, 2003; Xayph, 2005). Commercial concentrates are generally used as supplements to goat. Considering the cost and availability of concentrates, it is wise to use it most judiciously. As an alternate source, tree leaves, green forages are used to overcome the feed gap that arises from seasonal fluctuation. Jackfruit (Artocarpus heterophyllus), Bhumura (Terminalia bellerica) and Papaya (Carica papaya), and are the locally available trees in Assam and are also relished by goat. Leaves of these trees can be used as a green fodder during drought period. Studies have shown that these medicinal plant leaves possess antihelmintic, antiprotozoan, antibacterial, antifungal, antiviral, antiinflammatory, antihypertensive, hypoglycemic and hypolipidemic, wound healing, antitumor, free-radical scavenging, antisickling, neuroprotective, diuretic, abortifacient and antifertility activities (Yadav and Agarwala, 2011; Maisarah et al., 2013; Raaman, 2015) as they are rich source of phytochemicals such as tannin, saponin, phenolic compounds, alkaloids, flavonoid, carotenoid, cardiac glycosides, steroid, ascorbic acid, vitamin E, papain enzyme etc. (Varisha et al., 2013). But the information related to the potential of these tree leaves along with substrate feed in respect of rumen microbial enzyme activities including carboxymethyl cellulase, $\beta$-glucosidase and xylanase and their effect on growth performance of goat is very limited. Therefore, the present experiment was conducted in order to understand about the changes of rumen microbial enzymes and growth performances in Assam hill goat by feeding locally available plants along with substrate ration.

\section{MATERIALS AND METHODS}

The experiment was conducted in the Department of Veterinary Biochemistry, College of Veterinary Science, Assam Agricultural University, Khanapara, Guwahati-781022 under the DBT Twinning Project (NER) entitled "Role of plants as a modifier of rumen to reduce methane production and improve productivity in small animals" during the study period (from March, 2016 to May, 2016).

\section{Collection of plant materials}

For the present study, fresh and disease free leaves of three locally available medicinal plants Artocarpus heterophyllus (Jackfruit), Terminalia bellerica (Bhumura) and Carica papaya (Papaya) were collected from six different places in and around Guwahati, Assam, India. These leaves were collected based on palatability and ease of availability.

\section{Processing of plant leaves}

The plant materials were washed under running tape water followed by distilled water to remove dust and then cut into small pieces, dried under sun and pulverized into fine powder in a grinding machine. The powder was then kept in small plastic bags away from the light, heat, moisture with proper labelling till further analysed.

\section{Experimental animals}

The experimental animals were reared in Experimental Animal Shed, Department of Veterinary Physiology, College of Veterinary Science, Assam Agricultural University, Khanapara, Guwahati-781022, Assam, India. The experiment was conducted for a period of 90 days (from March, 2016 to May, 2016). A total of eighteen Assam hill (local) kids of 3-4 months of age and average body weight of 6-8 $\mathrm{kg}$ were procured locally. Prior to the arrival of the procured goats, the pens and surrounding environment were thoroughly cleaned and disinfected with anti-septic solutions. The animals were conditioned for a period of 15 days prior to start of the actual experiment and given standard ration/ substrate feed, green grasses. During the study period, the animals were given prophylactic treatment consisting of deworming for endo and ecto parasites. Everyday animal sheds, wooden floors, watering and feeding pans were cleaned to avoid microbial contaminations. The experimental animals were housed in a well-ventilated goat shed having a wooden floor. Goats were maintained under semi-intensive system. Animals were given substrate feed two times in a day (morning and evening) and water was given ad libitum. After feeding they were turned out for natural grazing from 9.00 A.M. to 12.30 P.M. and again from 2.30 P.M. to 5.30 P.M. This schedule was followed till the end of the experiment. 


\section{Design of the experiment}

The animals were divided into three (3) groups viz. Control (Substrate feed), T (Plant leaves@ @ \% level of Total Mixed Ration) and $\mathrm{T}_{2}$ (Plant leaves @ 10\% level of Total Mixed Ration) containing six (6) animals in each group irrespective of sex.

\section{Experimental dietary treatment}

Substrate ration or feed was prepared using conventional feed ingredients viz. maize, wheat bran, ground nut cake, mineral mixture, salt and vitamins (Table 1). The calculated nutritive value of the substrate feed was $13.89 \%$ DCP and $78.89 \%$ TDN. The three medicinal plant leaves viz. Artocarpus heterophyllus (Jackfruit), Terminalia bellerica (Bhumura) and Carica papaya (Papaya) were mixed in the ratio of $1: 1: 1$ and mixed in the substrate feed at concentration $5 \%$ and $10 \%$ level.

Table 1: Composition of the ration given to the animals with or without medicinal plant leaves

\begin{tabular}{llll}
\hline Ingredients & Control & $\begin{array}{l}\mathbf{T}_{\mathbf{1}} \\
\mathbf{( 5} \text { \% level })\end{array}$ & $\begin{array}{l}\mathbf{T}_{\mathbf{2}} \\
(\mathbf{1 0} \% \text { level })\end{array}$ \\
\hline Maize & 65 & 56 & 60 \\
Wheat bran & 20 & 25 & 20 \\
GNC & 12 & 11 & 7 \\
Mineral mixture & 2 & 2 & 2 \\
Salt & 1 & 1 & 1 \\
Medicinal leaves & - & 5 & 10 \\
\hline Total & $\mathbf{1 0 0}$ & $\mathbf{1 0 0}$ & $\mathbf{1 0 0}$ \\
\hline
\end{tabular}

\section{Collection and processing of rumen liquor}

Rumen liquor was collected as per the standard method (Singh and Kundu, 2010). After collection, rumen liquor was processed as per the standard method (Singh et al., 2011) for estimation of fibre degrading enzymes viz. carboxymethyl cellulase, $\beta$-glucosidase and xylanase.

\section{Estimation of carboxymethyl cellulase enzyme activity}

Carboxymethyl cellulase is also known as endoglucanse. The method described by Miller (1959) was used to estimate the carboxymethyl cellulase enzyme activity.

\section{Estimation of B-glucosidase (B- d- glucoside} glucohydrolase) enzyme activity

The enzyme catalyses the hydrolysis of cellobiose and short chain oligosaccharides to release glucose. The activity was measured as per the method described by Shewale and Sadana (1978).

\section{Estimation of xylanase (1, 4- 8 - xylan xylano hydrolase) enzyme activity}

The enzyme catalyses the hydrolysis of xylan and releases D-xylose. The activity was measured as per the method described by Miller, 1959.

\section{Weighing of the animals}

The body weight of the individual animal was recorded at 7.00 A.M. (before offering feed and water) from beginning of the experiment ( 0 day) till the end of the experiment (90 days) at 30 days interval.

\section{Statistical analysis}

The statistical analysis of the experimental data were carried out according to the method described by Snedecor and Cochran (1994).

\section{RESULTS AND DISCUSSION}

The carboxymethyl cellulase enzyme activity ( $\mu \mathrm{mol}$ glucose $/ \mathrm{ml} / \mathrm{h}$ ) of all the three groups of Assam hill goat are presented in Table 2. The carboxymethyl cellulase enzyme activities ( $\mu \mathrm{mol}$ glucose $/ \mathrm{ml} / \mathrm{h}$ ) in rumen liquor of control, $\mathrm{T}_{1}$ and $\mathrm{T}_{2}$ groups of Assam local goat were recorded as $2.80 \pm 0.01,2.77 \pm 0.01$ and $2.83 \pm 0.01$ respectively with overall mean value of $2.80 \pm 0.01 \mu \mathrm{mol}$ glucose $/ \mathrm{ml} / \mathrm{h}$. The values of carboxymethyl cellulase enzyme recorded in the present experiment were in close agreement with the earlier reports (Agarwal et al., 2002; Wang et al., 2016). Analysis of variance revealed significant $(\mathrm{P}<0.05)$ differences between $T_{1}$ and $T_{2}$ groups but no significant differences were observed between control and $\mathrm{T}_{1}$ groups \& also between control and $\mathrm{T}_{2}$ groups of Assam local goat which may be attributed to the difference in fibre content of the ration supplied to $T_{1}$ and $T_{2}$ groups of Assam local goats at $5 \%$ and $10 \%$ level of total mixed ration respectively. A higher proportion of fibre content in the $10 \%$ level of 
Table 2: Carboxymethyl cellulase, $\beta$ - glucosidase and xylanase enzyme activity (Mean $\pm \mathrm{SE}$ ) in rumen liquor of Assam hill goat

\begin{tabular}{llll}
\hline Groups & $\begin{array}{l}\text { Carboxymethyl cellulase } \\
(\boldsymbol{\mu m o l} \text { glucose/ } \mathbf{m l} / \mathbf{h})\end{array}$ & $\begin{array}{l}\boldsymbol{\beta} \text { - Glucosidase } \boldsymbol{( \boldsymbol { \mu m o l }} \\
\mathbf{p} \text {-nitrophenol/ml/min) }\end{array}$ & $\begin{array}{l}\text { Xylanase } \\
(\boldsymbol{\mu m o l} \mathbf{x y l o s e} / \mathbf{m l} / \mathbf{m i n})\end{array}$ \\
\hline Control & $2.80^{\mathrm{ac}} \pm 0.01$ & $0.35^{\mathrm{NS}} \pm 0.01$ & $2.90^{\mathrm{NS}} \pm 0.01$ \\
$\mathrm{~T}_{1}$ & $2.77^{\mathrm{ab}} \pm 0.01$ & $0.36^{\mathrm{NS}} \pm 0.01$ & $2.92^{\mathrm{NS}} \pm 0.01$ \\
$\mathrm{~T}_{2}$ & $2.83^{\mathrm{c}} \pm 0.01$ & $0.37^{\mathrm{NS}} \pm 0.01$ & $2.93^{\mathrm{NS}} \pm 0.01$ \\
\hline Overall Mean $\pm \mathrm{SE}$ & $2.80 \pm 0.01$ & $0.36 \pm 0.00$ & $2.92 \pm 0.01$ \\
\hline
\end{tabular}

a, b, c Means with different subscripts in a column differ significantly $(\mathrm{P}<0.05)$; ${ }^{\mathrm{NS}}$ Non-significant.

Table 3: Average body weight (Mean \pm SE) in different groups of Assam hill goats on different days of feeding

\begin{tabular}{llllll}
\hline \multirow{2}{*}{ Groups } & \multicolumn{5}{c}{ Average body weight per animal (kg) } \\
\cline { 2 - 6 } & 0 day & $\mathbf{3 0}$ days & $\mathbf{6 0}$ days & $\mathbf{9 0}$ days & Overall Mean \pm SE \\
\hline Control & $6.80^{\mathrm{a}} \pm 0.20$ & $7.20^{\mathrm{b}} \pm 0.23$ & $8.03^{\mathrm{c}} \pm 0.20$ & $8.93^{\mathrm{d}}{ }_{\mathrm{A}} \pm 0.21$ & $7.74_{\mathrm{A}} \pm 0.20$ \\
$\mathrm{~T}_{1}$ & $6.98^{\mathrm{a}} \pm 0.27$ & $7.78^{\mathrm{b}}{ }_{\mathrm{AB}} \pm 0.36$ & $8.65^{\mathrm{c}}{ }_{\mathrm{AB}} \pm 0.40$ & $9.45^{\mathrm{d}}{ }_{\mathrm{AB}} \pm 0.42$ & $8.22_{\mathrm{B}} \pm 0.26$ \\
$\mathrm{~T}_{2}$ & $7.20^{\mathrm{a}} \pm 0.27$ & $7.92^{\mathrm{b}}{ }_{\mathrm{BC}} \pm 0.37$ & $8.75^{\mathrm{c}}{ }_{\mathrm{BC}} \pm 0.41$ & $9.62^{\mathrm{d}}{ }_{\mathrm{BC}} \pm 0.43$ & $8.37_{\mathrm{BC}} \pm 0.26$ \\
\hline Overall Mean $\pm \mathrm{SE}$ & $6.99^{\mathrm{a}} \pm 0.14$ & $7.63^{\mathrm{b}} \pm 0.19$ & $8.48^{\mathrm{c}} \pm 0.21$ & $9.33^{\mathrm{d}} \pm 0.21$ & \\
\hline
\end{tabular}

A, B, C Means with different subscripts in a column differ significantly between groups $(\mathrm{P}<0.05)$; ${ }^{\text {a, b, c, d }}$ Means with different superscript in a row differ significantly between days $(\mathrm{P}<0.01)$.

total mixed ration supplied to the $T_{2}$ group would have stimulated the microbial enzyme system responsible for its hydrolysis resulting in more ruminal enzyme activity of carboxymethyl cellulase (Vaithiyanathan et al., 2015). Lower carboxymethyl cellulase enzyme activity in $\mathrm{T}_{1}$ group supplied with $5 \%$ level of total mixed ration contributed to their poor cellulose digestibility indicating significance of the rumen ciliated protozoa in fibre digestion (Santra and Karim, 2002; Kamra et al., 2003; Agarwal et al., 2004; Vaithiyanathan et al., 2015).

The $\beta$-glucosidase enzyme activity ( $\mu \mathrm{mol}$ p-nitrophenol/ $\mathrm{ml} / \mathrm{min}$ ) of all the groups of Assam hill goat are presented in Table 2 . The $\beta$-glucosidase enzyme activities ( $\mu \mathrm{mol}$ p-nitrophenol $/ \mathrm{ml} / \mathrm{min}$ ) in rumen liquor of control, $\mathrm{T}_{1}$ and $\mathrm{T}_{2}$ groups of Assam local goat were recorded as $0.35 \pm$ $0.01,0.36 \pm 0.01$ and $0.37 \pm 0.01$ respectively with overall mean value of $0.36 \pm 0.00 \mu \mathrm{mol} \mathrm{p}$-nitrophenol $/ \mathrm{ml} / \mathrm{min}$. Analysis of variance revealed non-significant differences amongst all the groups of Assam local goat in respect of $\beta$-glucosidase enzyme. These findings were in close agreement with the earlier reports (Agarwal et al., 2002; Kamra et al., 2003; Singh, 2004) where they have reported activity of $\beta$ - glucosidase enzyme as $0.20 \pm 0.2$ to $0.18 \pm$ $0.04 \mu \mathrm{mol} \mathrm{pnp} / \mathrm{min} / \mathrm{ml}$. Therefore, the total mixed ration supplied to $T_{1}$ and $T_{2}$ groups of Assam local goats did not alter the ruminal environment and digestion.

The xylanase enzyme activity ( $\mu \mathrm{mol} x y l o s e / \mathrm{ml} / \mathrm{min}$ ) of all the groups of Assam hill goat are presented in Table 2. The xylanase enzyme activities ( $\mu \mathrm{mol}$ xylose $/ \mathrm{ml} / \mathrm{min}$ ) in rumen liquor of control, $\mathrm{T}_{1}$ and $\mathrm{T}_{2}$ groups of Assam local goats were recorded as $2.90 \pm 0.01,2.92 \pm 0.01$ and 2.93 \pm 0.01 respectively with overall mean value of $2.92 \pm 0.01$ $\mu \mathrm{mol} x y l o s e / \mathrm{ml} / \mathrm{min}$ which were in close agreement with the earlier reports (Agarwal et al., 2002; Wang and Wang, 2016). Statistically the xylanase enzyme activities ( $\mu \mathrm{mol}$ xylose $/ \mathrm{ml} / \mathrm{min}$ ) were found to be non-significant amongst control, $\mathrm{T}_{1}$ and $\mathrm{T}_{2}$ groups of Assam local goats. These findings were in close agreement with the earlier reports (Agarwal et al., 2004; Vaithiyanathan et al., 2015; Wang and Wang, 2016) indicating no effect in the rumen micro flora and digestion in Assam local goats.

The average body weight ( $\mathrm{kg}$ per animal) of control, $\mathrm{T}_{1}$ and $\mathrm{T}_{2}$ groups of Assam hill goats are presented in Table 3 . The average body weight ( $\mathrm{kg}$ per animal) recorded in the present experiment varied from $6.80 \pm 0.20$ to $8.93 \pm$ 0.21 with overall mean value of $7.74 \pm 0.20 \mathrm{~kg}$ per animal for control, $6.98 \pm 0.27$ to $9.45 \pm 0.42 \mathrm{~kg}$ per animal with overall mean value of $8.22 \pm 0.26 \mathrm{~kg}$ per animal for $\mathrm{T}_{1}$, 
$7.20 \pm 0.27$ to $9.62 \pm 0.43 \mathrm{~kg}$ per animal with overall mean value of $8.37 \pm 0.26 \mathrm{~kg}$ per animal for $\mathrm{T}_{2}$ groups of Assam hill goats respectively.

The average body weight ( $\mathrm{kg}$ per animal) recorded in the present experiment showed increased significant trend $(\mathrm{P}<0.01)$ from 0 to 90 days of experiment in all the groups where higher value was obtained in $\mathrm{T}_{2}$ group $(9.62 \pm 0.43$ $\mathrm{kg}$ /animal) of Assam hill goat at 90 days of experiment which might be due to increase in age and also due to higher nutritive value of medicinal plant leaves at $10 \%$ level of total mixed ration (Chukwuku et al., 2013). The body weight values recorded in the present experiment showed significant differences $(\mathrm{P}<0.01)$ between 30,60 and 90 days of experiment in all the groups and the values recorded during 30,60 and 90 days of experiment were also found to be statistically significant $(\mathrm{P}<0.05)$ between control and $\mathrm{T}_{2}$ groups of Assam hill goat but not between control and $T_{1}$ groups. From the experiment, it can be observed that $\mathrm{T}_{2}$ group showed better result by feeding $10 \%$ level of leave mixture of the total mixed ration. These findings recorded in the present experiment were in close agreement with the earlier reports (Khaing et al., 2015; Nath et al., 2017).

\section{CONCLUSION}

From the present experiment, it could be concluded that out of the three fibre degrading enzymes viz. carboxymethyl cellulase, $\beta$-glucosidase and xylanase, the activity of carboxymethyl cellulase enzyme was found to be significantly $(\mathrm{P}<0.05)$ higher in $\mathrm{T}_{2}$ group indicating higher fibre degradability in rumen and the growth performances in $T_{2}$ group were also found to be better $(P<0.01)$ than control and $\mathrm{T}_{1}$ groups of Assam hill goat. Finally it can be inferred that supplementing the total mixed ration for goat with $10 \%$ was better than $5 \%$ of the leave mixture.

\section{ACKNOWLEDGEMENTS}

The authors wish to extend their gratitude to the Head of the Department of Veterinary Biochemistry and the P.I., DBT Twinning Project entitled "Role of plants as a modifier of rumen to reduce methane production and improve productivity in small animals", Department of Veterinary Biochemistry, College of Veterinary Science, Assam Agricultural University, Khanapara, Guwahati, Assam, India for providing all the necessary facilities for carrying out the research works during the study period.

\section{REFERENCES}

Agarwal, N., Karmaa, D.N., Chaudhary, L.C., Agarwal, I., Shahoo, A. and Patha, N.N. 2002. Microbial status and rumen enzyme profile of crossbred calves fed on different microbial feed additives. Appl. Microbiol., 34(5): 329-336.

Agarwal, N., Saxena, J., Saha, S., Chaudhary, L.C. and Kamra, D.N. 2004. Changes in fermentation characteristics, microbial populations and enzyme profile in the rumen of buffalo as affected by roughage level in the diet. Bubalus bubalis, 3: 81-90.

Chukwuku, K.S., Iwuagwu, M. and Uka, U.N. 2013. Evaluation of nutritional component of Carica papaya L. at different stages of ripening. IOSR J. Pharma. Biol. Sci., 6(4): 13-16.

Kamra, D.N., Saha, S., Bhatt, N., Chaudhary, L.C. and Agarwal, N. 2003. Effect of diet on enzyme profile, biochemical changes and in sacco degradability of feeds in the rumen of buffalo. Asian-Aust. J. Anim. Sci., 16: 374-379.

Khaing, K.T., Loh1, T.C., Ghizan, S., Halim, R.A. and Samsudin1, A.A. 2015. Feed intake, growth performance and digestibility in goats fed whole corn plant silage and Napier grass. Mal. J. Anim. Sci., 18(1): 87-98.

Maisarah, A.M., Asmah, R. and Fauziah, O. 2013. Proximate analysis, antioxidant and anti-proliferative activities of different parts of Carica Papaya. J. Nutr. Food Sci., 4(2): 1-7.

Miller, G.L. 1959. Modified DNS method for reducing sugars. Anal. Chem., 31: 426-428.

Nath, R., Baruah, K.K., Sarma, S., Roy, D.C., Bhuyan, R., Dutta, M. and Deka, N. 2017. Effect of meat composition and carcass characteristics of goat feeding mixture of different medicinal leaves of North East India. J. Pharmacogn. Phytochem., 6(1): 211-213.

$19^{\text {th }}$ Livestock Census-2012. Ministry of Agriculture, Department of Animal Husbandry, Dairying \& Fisheries, Krishi Bhawan, New Delhi - 110001 .

Phengsavanh, P. 2003. Goat production in smallholder farming systems in Lao PDR and the possibility of improving the diet quality by using Stylosanthes guianensis CIAT 184 and Andropogon gayanus cv Kent. MSc. Thesis. Department of Animal Nutrition and Management, Swedish University of Agricultural Sciences, Uppsala, Sweden.

Raaman, N. 2015. Thin layer chromatographic analysis and antioxidant activities of methanol extract of leaves of Carica papaya L., Int. J. Adv. Pharm. Biol. Chem., 4(2): 2277- 4688.

Santra, A. and Karim, S.A. 2002. Influence of ciliate protozoa on biochemical changes and hydrolytic enzyme profile in the rumen ecosystem. J. Appl. Microbiol., 92: 801-811.

Shewale, J.G. and Sadana, J.C. 1978. Cellulase and $\beta$-glucosidase production by a basidomycete species. Can. J. Microbiol., 24: 1204-1216. 
Singh, B., Chaudhary, L.C., Agarwal, N. and Kamra, D.N. 2011. Effect of feeding Ficus infectoria leaves on rumen microbial profile and nutrient utilization in goats. Asian-Aust. J. Anim. Sci., 24(6): 810 -817.

Singh, S. 2004. Metabolic and Rumen Microbial Activities in Sheep and Goats on grass-tree leaves/shrubs dietary regimens. Technical Bulletin. Indian Grassland and Fodder Research Institute, Jhansi, India.

Singh, S. and Kundu, S.S. 2010. Effect of tropical browse leaves supplementation on rumen enzymes of sheep and goats fed Dichanthium annulatum grass-based diets. Trop. Anim. Health. Prod., 42: 1181-1187.

Snedecor, G.W. and Cochran, W.G. 1994. Statistical Methods. $1^{\text {st }}$ East-West Press Edn., Affiliated East-West Private Ltd., New Delhi.

Vaithiyanathan, S., Saravanakumar, S., Reddy, P.B. and Ramakrishna, C. 2015. Seasonal variation in fibre degrading enzymes activities in the rumen contents of slaughtered sheep, goat and buffalo. Anim. Nutr. Feed Technol., 15: 111120
Varisha, A., Ansari, S.H., Kamran, J., Naquvi, P.A., and Ahmad, A. 2013. Development of quality standards of Carica papaya Linn. leaves. Der Pharmacia Lettre, 5(2): 370-376.

Wang, C., Liu, Q., Guo, G., Huo, W.J., Ma, L., Zhang, Y., Pei, C., Zhang, S. and Wang, H. 2016. Effects of dietary supplementation of rumen-protected folic acid on rumen fermentation, degradability and excretion of urinary purine derivatives in growing steers. J. Arch. Anim. Nutr., 70(6): 441-454.

Wang, S.P. and Wang, W.J. 2016. Effects of dietary supplementation of Chinese herb medicine mixture on rumen fermentation, nutrient digestion and blood profile in goats. $S$. Afr. J. Anim. Sci., 46(3): 247- 260.

Xayph, S. 2005. Goat production in smallholder farming systems in lowlands Lao PDR and an evaluation of different forages for growing goats MSc. Thesis. Department of Animal Nutrition and Management, Swedish University of Agricultural Sciences, Uppsala, Sweden.

Yadav, R.N.S. and Agarwala, M. 2011. Phytochemical analysis of some medicinal plants. J. Phytol., 3(12): 10-14 